\title{
顆粒球減少症におけるロ腔病変について
}

大森基夫・阿部俊裕・秋葉正一・追川哲雄

泉廣次・山本浩 嗣*. 金丸幸二**

\section{Clinical observation of oral lesion in granulocytopenia}

\author{
Motoo Ohmori - Toshihiro Abe - Masakazu Akrba - Tetsuo Orkawa \\ Hirotsugu Izum - Hirotsugu Yamamoto* - Koji KanamarU**
}

緒

言

顆粒球減少症は，骨䯣における顆粒球系細胞の低形成 や成熟障害，あるいは末梢に拈ける破壊元進により，末 梢血に拈いて顆粒球の著減あるいは消失をみる疾患であ る.

本症は1922年, Schultz が急激な高熱をもって発病 し, 口腔粘膜の壊死，重篤な扁桃炎をおこし，末梢血中 顆粒球の全く消失する原因不明の，予後不良な疾患を報 告したのにはじまるとされている1). その後, 本症の概 念も当時とはかなり変わってきているが，発症原因とし てある種の薬剤との関連が考えられるよらになり， た，ある種の疾患に継発することも明らかになり，治療 に関しても抗生物質，副腎皮質ホルモンの応用，さらに $\gamma$ ーグロブリン製剂の導入等により本症の予後は以前に比 べて著しく改善された。しかし，現在でも原因不明の症 例も多くみられ，特殊な病型を呈するすの2)，さらには 先天性, 家族性に発生するものもみられ ${ }^{3}$, 臨床上重要 な疾患である。

今回わたくしたちは，7歳女見にみられた発症原因不 明の顆粒球減少症を初診以来 4 年間にわたり, 口腔病変 を主とした症状の経過を観察する機会を得たので，血液

日本大学松戸歯学部第 1 口腔外科学教室（主任： 泉 暨次教授)

*日本大学松戸歯学部臨休病理学教室（主任：大竹 繁雄助教授)

**国保旭中央病院㳡口科

The First Department of Oral Surgery, Nihon University School of Dentistry at Matsudo (Chief: Prof. Hirotsugu Izumi)

*The Department of Clinical Pathology, Nihon University School of Dentistry at Matsudo (Chief: Assist. Prof. Shigeo Ohtake)

**The Department of Oral Surgery, Asahi Central Hospital

受付日：昭和55年 2 月25日
学的所見，治療および予後についても検討を加え，その 概要を報告する

症例

患 者：11歳 (初診時 7 歳) 女児.

初 診: 昭和50年10月—.

主 訴: 歯肉の発赤, 腫脹.

家族歴：父母，同胞 2 名む健在であり，母親の妊娠厢 にも異常はない.

既往歴：3歳頃より易感染性を示し, 頻回に皮下膿啺 を繰り返していた。 また，日頃から軽度の労作にて疲れ やすく，風邪むひきやすく，すぐに発熱をみていた。 そ の後，—病院小見科にて顆粒球減少症と診断され， 対症療法を主とした治療を受けていた。

現病歴：3歳頃から全顎にわたる歯肉の発赤, 尰脹を 認め，しばしば同部の急性炎症を繰り返していた。 その 都度抗生物質の投与を中心とする消炎療法で処置されて いたが，昭和51年 4 月，右側煩部の腫脹を伴ら急性䫑炎 の症状を呈し, 通常の処置にては軽快せず, 口病院 歯口科に入院の上, 治療を行った.

その後, 昭和 54 年 10 月までに二度の入院治療を含め, 現在も随時および定期的に外来通院中である。

第 1 回入院時現症

全身所見：身長 $118 \mathrm{~cm}$, 体重 $18 \mathrm{~kg}$ で体格, 栄着と もに中等度である，顔色は紅潮し， $38.8^{\circ} \mathrm{C}$ の発熱を認 め, 全身倦志感, 脱力感を訴える、脾尰は触診したが触 れなかった。

局所所見：顔貌は右側頓部の腫脹のため左右非対称 で，顎下リンパ節は両側とす小指頭大に腫大し，可動性 である、ときには口腔のみならず，眼睑周困にる発赤， 腫脹を認め，眼瞼炎の症状を呈する（写真1).

口腔内は全簤にわたり齿肉の尰脹が認められ，特に上 下顎前蒾部歯肉に著明である。

下䝷前齿部においては腫脹は唇側のみならず舌側にも 及び，軟らかく，易出血性である，さらに歯頸部を中心 


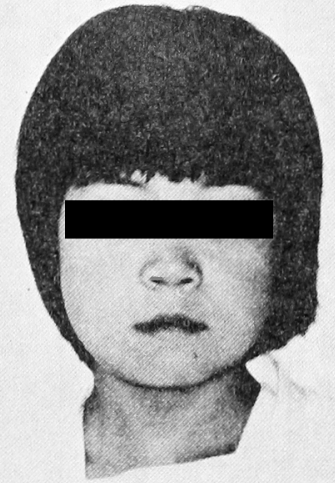

写真 1 顔貌所見

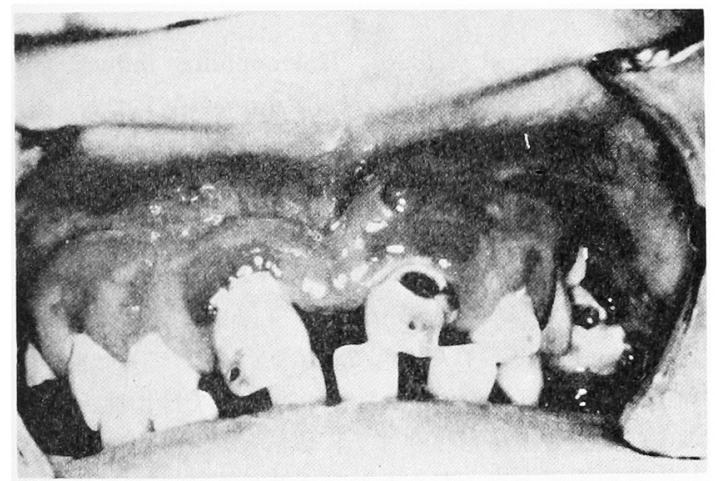

写真 2 口腔内所見

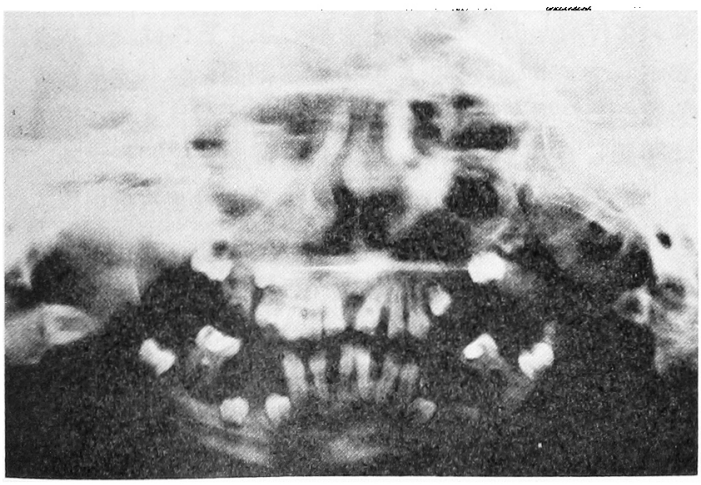

写真 3 X線写真所見

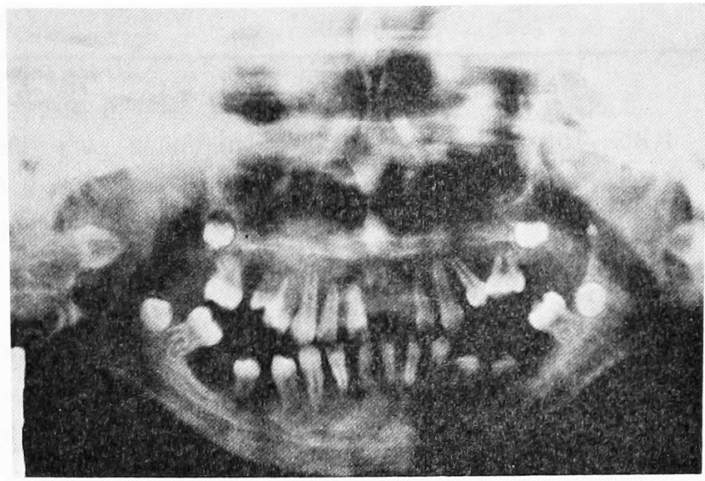

写真 4 X線写真所見

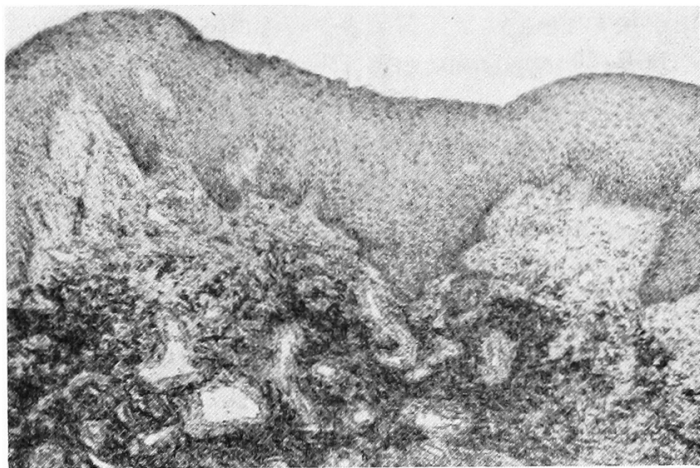

写真 5 病理組織像(へマトキシリン・エオシン染 色, $\times 40)$

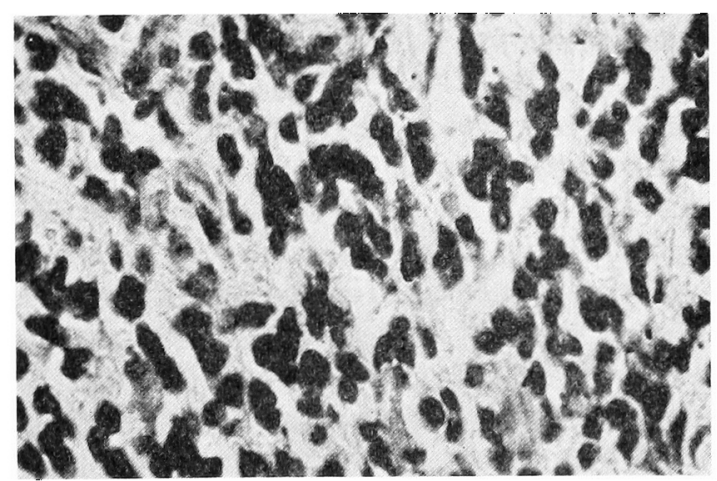

写真 6 病理組織像（ウンナ・ハッペンハイム染色 $\times 400$ )

とした歯肉に赤味を增した境界明膫な発赤がみられ，全 域に散在している，扁桃住中等度に肥大し，発赤を伴 い，咽頭にも軽度の発赤が認められる。歯牙は多数がう 蝕に侵され, 位置怙よび萌出方向の異常がみられ, 全歯 牙とあかなりの動摇を認める(写真2).

X線検査：オルソパントモグラムに执いて下顠骨の広 
表 1 臨床検査成績, 血液 1

\begin{tabular}{|c|c|c|c|c|c|}
\hline & '75.10. & '76. 4. & '77.10. & '78.4. & '79.2. \\
\hline $\mathrm{RBC} \quad 10^{4} / \mathrm{mm}^{3}$ & 440 & 406 & 415 & 448 & 436 \\
\hline $\mathrm{Hgl} \mathrm{g} / \mathrm{d} l$ & 11.1 & 9.8 & 10.4 & 11.3 & 10.3 \\
\hline $\mathrm{Ht} \%$ & 33 & 30 & 32 & 36 & 33 \\
\hline Platelet $\quad 10^{4} / \mathrm{mm}^{3}$ & 53.8 & 48.4 & 73.6 & 38.2 & 44. 3 \\
\hline Retic \% & & & 26 & & \\
\hline $\mathrm{WBC} / \mathrm{mm}^{3}$ & 4,400 & 6,300 & 6,900 & 6,300 & 4,900 \\
\hline N Stag \% & 4 & 0 & 4 & 0 & 2 \\
\hline Seg $\%$ & 5 & 0 & 21 & 0 & 14 \\
\hline Eosino \% & 6 & 4 & 4 & 4 & 5 \\
\hline Baso \% & 2 & 0 & 1 & 2 & 2 \\
\hline Mono $\%$ & 16 & 17 & 16 & 34 & 11 \\
\hline Lymph \% & 67 & 79 & 54 & 60 & 66 \\
\hline BSR $30 \mathrm{~min} . \mathrm{mm}$ & 48 & 60 & 66 & 20 & 32 \\
\hline 60 & 97 & 115 & 118 & 68 & 78 \\
\hline 120 & 133 & 135 & 138 & 118 & 122 \\
\hline Bleeding time & $4^{\prime} 0^{\prime \prime}$ & & & & \\
\hline Coagulation time & $9^{\prime} 30^{\prime \prime}$ & & & & \\
\hline
\end{tabular}

範囲にわたる吸收がみられ，雨牙はほとんどが顎骨内に 植立して抢らず，根尖が骨から遊離しているものが多 い. X線写真は左が昭和 51 年 8 月, 右が昭和 54 年 1 月の ものである（写真 3，4）.

\section{臨床検査所見}

血液学的所見：末梢血液像では, 白血球数はほぼ正常 籁囲内にあったが, 好中球は消失し, 反面単球, リンパ 球の相対的増加がみられた. 赤沈值は30分值, 60 分値之 もに著しい促進がみられた。 その他の血液像, 凝血学的 検査には異常を認めなかった（表1）.

血清学的検査：CRP は強陽性, RA も陽性を示し, 表 2 にみられるごとくこれらの反応はその後も常に陽性 を示した。

蛋白分画においては 疫グロブリン分画においても IgG の著しい增加がみら れ， IgA， IgM も增加が認められた（表 2 ）。

免疫学的検査：白血球自己抗体により花起される本症 も考兄, 白血球凝集反応, 直接法および間接法による抗 グロブリン消費試験を行ったが，ともに陰性であり，完 全抗体，不完全抗体ともに証明されなかった。

骨髄像：腸骨穿刺による骨髄所見では骨䯣系に芽球の 増加, 成熟停止（骨䯣球以下の成熟顆粒球をほとんど認 めない), 単球系細胞の增加といった多彩な形態異常を 䜑めるが，巨核球は正常で，赤血球系にも著しい変化を 認めなかった。

細菌検査所見：主として咽頭，崡肉部の分泌物あるい は擦過により採取した材料の培羕検查で検出されたもの
は Streptococcus viridans, Haemophilus influenzae, Neisseria および Staphylococcus aureus などであった. 病理組織学的所見：歯肉の粘膜上皮下結合織は一部浮 腫性あるいは線維性で中等度の血管抁張があり, 形質細 胞を主体とし組織球，リンパ球を混在した著明な炎症性 細胞浸潤がびまん性にみられる（写真 5 ）。形質細胞の 細胞質はへマトキシリン・エオシン染色でアズキ色, ウ ソナ・バッペンハイム染色で赤染し，またラッセル小体

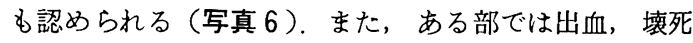
および細菌の集落も存在する，表層は錯角化を示す肥厚 した重層扁平上皮でお扔われ，上皮突起は不規則に延長 している.

$\overline{6} \mid$ の歯冠は大部分崩壊しており，艾合面側には壊死 物質を付着している，その下層の象牙質には珠数状拉大 を示しへマトキシリンに濃染する細菌を含有する細管が 多数みられる。根部象牙質には球間区が目立ち，根尖孔 は閉鎖していない，セメント質は軽度肥厚した二次セメ ント質で不規則な吸収がある。少数付着せる歯根膜には 上記の炎症性細胞浸潤が認められる。

治療および経過 : 初診以来 4 年間の口腔領域病変のお もな経過は次のと扣りである。

昭和51年 4 月日日：可浸麻下に抜歯.

昭和51年 4 月日日：可部抜歯後感染から急性顎炎を 併発して入院. 同日日, 軽快退院.

昭和 52 年 10 月曰日：|1 拔噵. その後約 1 年にわたり 根管治療するも治病せず。

昭和52年12月口日： $\overline{\mathrm{D}}$ 部急性靧炎にて 消炎後抜歯一 
表 2 臨床検査成續，血液 2

\begin{tabular}{|c|c|c|c|}
\hline & '76. 4. & '77.10. & 79.2. \\
\hline GOT & 13 & 15 & 15 \\
\hline GPT & 4 & 3 & 4 \\
\hline ALP & 13. 3 & 16. 3 & 19.0 \\
\hline LDH & 240 & 220 & 240 \\
\hline LAP & 160 & 180 & 190 \\
\hline ZTT & 31.0 & 30.6 & 31.2 \\
\hline TTT & 8.0 & 8.4 & 9.2 \\
\hline Creat $\mathrm{mg} / \mathrm{d} l$ & & & 0.6 \\
\hline T. Ch mg/d $l$ & 146 & 142 & 143 \\
\hline T. Protein $\mathrm{g} / \mathrm{d} l$ & 9.1 & 8.5 & 9.0 \\
\hline $\mathrm{A} / \mathrm{G}$ & & 0.46 & 0.87 \\
\hline Alb $\%$ & & 31.6 & 46.5 \\
\hline Gl $\quad \alpha_{1}$ & & 4.5 & 3.6 \\
\hline$\alpha_{2}$ & & 12.8 & 8.0 \\
\hline$\beta$ & & 7.7 & 9.6 \\
\hline$r$ & & 40.2 & 32.0 \\
\hline $\mathrm{BUN} \quad \mathrm{mg} / \mathrm{d} l$ & 7 & 7 & 7 \\
\hline Uric acid & 3.0 & & 3.0 \\
\hline CRP & $5+$ & $3+$ & $3+$ \\
\hline RA & + & + & \pm \\
\hline IgG $\mathrm{mg} / \mathrm{d} l$ & & 3,680 & 4,140 \\
\hline $\operatorname{IgA} \mathrm{mg} / \mathrm{d} l$ & & 885 & 960 \\
\hline $\operatorname{IgM} \mathrm{mg} / \mathrm{d} l$ & & 940 & 730 \\
\hline $\mathrm{IgE} \mathrm{IU} / \mathrm{m} l$ & & 440 & \\
\hline LE cell & & & - \\
\hline ASLO & & & 166 \\
\hline $\mathrm{Ch} \mathrm{E}$ & 0.68 & & 0.90 \\
\hline
\end{tabular}

抜雨後の治癒状態良好.

昭和53年 1 月 口曰 $\cdot \overline{6 / 6}$ 迷周組織炎のため 根管開放 後, 根管治療開始一治癒せす感染源となるため拔歯.

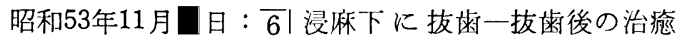
状態良好.

昭和53年11月曰日：| 6 同様に拔歯一翌日より左煩部, 周囲歯肉腫脹し, 治癒状態不良.

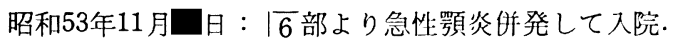
同22日軽快退院。

昭和53年12月日日：| 1 浸麻下に抜蒌。

昭和54年 1 月回 $\underline{6}$ 同抜歯.

昭和 54 年 8 月回： 1 同抜歯.

いずれも術前臨床桧查を行い，さらに抗生物質の術前 後投与により，拔歯後感染を防止できた。

昭和 54 年 9 月日日：下口唇咬稘が治㗪せず䟺瘍性口唇 炎となる。同四日ほぼ治痊。

昭和54年10月日日：111 久損部に対し義蒾作製のため 印象採得および洨合採得。
昭和54年10月回：1林 2 歯局部義歯装着。

なお，使用薬剈は抗生物質では Sencephalin, Cefamezin, Keflex, および Pasetocin であり，鎮痛剤では Mebron, Solantal などであった.

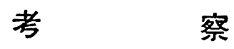

顆粒球減少症とは末梢血中を循環する顆粒球の絶対数 が低下した状態のことであり，無顆粒球症もこれと同様 であるが，より重篤な状態を示す場合に用いられている ようである4)

また，この用語の意味からすれば，これには好中球， 好酸球, 好塩基球および単球が含まれるが, 慣習上顆粒 球減少症は好中球減少症とほとんぞ同義に用いられてい るので4)，本症例においても顆粒球減少症といら名称に ならった，循環好中球の絶対数は，白血球数と好中球の 百分率を乗じた積であり，その正常䇛围は年齢により異 なるが，本症例のよらな学童期の小児に扔いては，白血

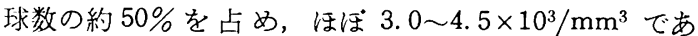

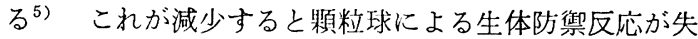
われるので，身体各部の感染症をひきおこしやすくな る。いいかえると, 好中球の減少の程度と細菌感染の危 除度は汪注平行し, 顆粒球数が $1,000 / \mathrm{mm}^{3}$ 以下になる と感染症にかかりやすくなり，500/ $\mathrm{mm}^{3}$ 以下になると 重篤な危険にさらされることになる ${ }^{6}$ ．すなわち，顆粒 球减少の程度, 病型に上り, 急性, 慢性, 反復性の感染 症をひき饾こすのが常である。

本症例の場合でも，末梢血検査において好中球数はほ ぼ 0 2,000/ $\mathrm{mm}^{3}$ の範囲内であるが，感染症の急性期 には好中球は消失し，間歇期には約 $500 \sim 2,000 / \mathrm{mm}^{3}$ 程 度出現することが認められている。したがって, 感染症 の重症度と好中球数は直接に関係する傾向にあったが, 白血球数はほとんど反応を示さず，好中球の減少に応じ て単球やリンパ球の增加がみられた。

本症例は骨嘓所見と末梢血所見とも合わせて，いわゆ る myelodysplastic syndrome あるいは hemopoietic dysplasia というような範疇に属するものと考えている.

骨髄所見は本症の重症度, 時期によっても異なるが, $\mathrm{Rohr}^{7}$ ) は，(1) 顆粒球系の生成不良型，（2）前骨䯣球 一骨髄球型，(3) 骨髄球一後骨㖪球型の 3 型に分類して いる.

本症例は，(2) 型に属し, maturation arrest の像を 示し，これらの幼若細胞が增殖して，より成熟した顆粒 球が注とんどみられない。この骨髄所見からみると， (1) 型の division arrrest でないのでその予後は比較的 良好ではないかと思われる。

顆粒球減少の機序は病態生理学的には，(1) 産生の低 下,（2）破壊の方進，（3）無効顆粒球の産生，（4）分布 異常，(5) 各種疾患に随伴などがあげられている2)。乙 
たがって発症原因としては，これらの病態をひき抗こす 状態の存在が考えられるが，いまだにその原因の不明な 場合が少なくない，本症例も問診や種々の検査等で精査 したにもかかわらず，明らかでなく，その後の治療にも 苦慮している。

現今, 顆粒球減少の主たる原因として，薬剤および放

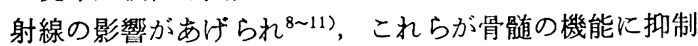
的作用して骨膊障害をおこし，顆粒球の産生を低下さ せたり, 免疫学的機序により顆粒球の破壊が方進され, その数の減少をおこすといわれている。しかし，一定量 投与すると必ずおこす抗癌剤や抗白血病剂を除いては特 定の人にたけ減少を扣こし, この発症には投与量, 投与 期間は関係なく, 少量, 短期間でも発症する ${ }^{2)}$ 本症例 では薬剤拉よび放射線の関与は一応否定されたが，生後 より発病までの服用薬郕をすべて確認したわけでなく， 発症原因としてなお検討を要するが, 病態生理学的に は，(1) の顆粒球の産生の低下によるものと思われる. Finch') (顆粒球減少症を薬物性のものと非薬物性のも のとに型別し, 白血球回転の面から妥当と思われる機序 を組み合わせて機能的分類をしている。しかし，この分 類も問題点が多く，ことに薬物性のものでは単一の機序 で成立すると考えられないものもあり，な捈討を要す るようである。

本症例を Finch ${ }^{4}$ ) の分類に従えば, Type I (顆粒球 系の增殖低下）に属し, 感染症の增覀期には好中球が消 失し，軽快期にはその数を增すことから，ある一定間隔 の周期的変動を示す周期性好中球減少症ではないかとも 考えている. 一般には通常 3 週間前後の周期で数日間に わたって発熱, 口腔粘膜や皮原の感染症を絽り返すこと を特微とし，これは好中球減少のみられる時期と一致す る1). 本症例ではこれらの感染症を月に $1 〜 2$ 回繰り返 し, 消炎療法に上り数日で軽快するが, その病変にはか なりの差がみられ，2〜3か月間急性炎症の発生をみな いこともあった。

臨床症状のらち, 口腔病変については, 一般に急性型

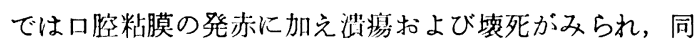
部は黄色または灭褐色の厚い苔で被われ，ときに出血を 認め，この卧痬は通常境界不明膫で次第にその大きさを 增し, 咽頭, 喉頭にも及び，ときには娞下困難，流涎， 開口障害などを認めることもある2)

一方, 慢性顆粒球減少症では感染が長期化し, 治癒が 遅く，治療にはあまり反応せず，しばしば急性化しかっ 多発性である。本症例では常に 慢性歯肉炎の症状を呈 し，ために歯牙はすべて動摇し，しばしば多発性に反復 性に急性炎症を繰り返している，ときには上記症状に加 之, 貲瘍性の炎症をみ，激しい咽頭痛を訴兄食物掑取に 困難をきたすこともあった，㐘肉と並んで扁桃も強い変 化をらけ, 特に口蓋扁桃は平常でもかなり腫大している が，発症時には発赤を伴ら著明な胛脤を生している。し
かし，好中球がないためか患部に膿煌を形成することは なく, 炎症性出液は漿液血性で, 量も極めて少なく, 歯肉を中心とした口腔粘膜の発赤, 腫脹がさらに著明に なるたけであった。この病状が他の一般の感染症と著し く異なり, 顆粒球減少症の病変として特徵があるように 思われる。 また，本症例ではこれらの粘膜の変化ととも 飞顎骨, 特に下買骨の広簌な吸収のみられることも特改 的であった，X線像のみでは歯肉の慢性炎症による骨の 吸収か，系統疾患に起因する発育不全か確定できない が，いずれにしろ粘膜のみならすす顎骨もその影響をらけ ることは明らかであった。

顆粒球减少症に捕ける口腔病変の病理組織像の記戴は

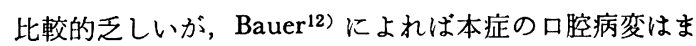
ず第 1 亿壊死性病変が崡肉盲歪に生し，次いで好中球の 减少による食菌作用の低下が細菌を增加させ，壊死およ び炎症が歯肉表層へ，さらに歯根膜，歯槽骨へ波及する といら，そしてその炎症性細胞は形澌細胞, 大食細胞, リンパ球が主体で，好中球はみられないと記載してい る. 自験例の歯肉の病理組織像にも Bauer ${ }^{12)}$ が述べた と同様な所見が認められた。炎症性細胞は形質細胞が主 体で組織球，リンパ球を混在しているが，臨床所見と同

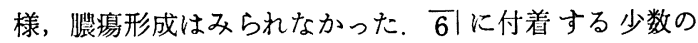
歯根膜にも炎症性細胞浸潤がみられたが，盲麗の位監的 関係は不明で炎症の発生機転打よび進展経路は明確にし 得ない。充宮崎は ${ }^{13)}$, 好中球減少症の血清免疫グロブ リンはすべて增加するが, 細胞性免疫は正常に保持され ると報告している。自験例の免疫グロブリンは $\mathrm{IgG}$, IgA，IgM のいずれも高值を示した。歯肉の免疫組織化 学的検索は行っていないが, 形質細胞は IgG, IgA の, リンパ球は IgM の産生細胞といわれているので14), 組 織像で形質細胞, リンパ球の浸潤を認めたことは血清免 疫グロブリンの增加と何らかの関係があると推察した W.

な括，細菌培養検查でも起炎菌は通常，口腔常在菌で ある場合が多く，これらによる二次感染と考えられ，顆 粒球の欠乏や防衛機㮖の変化, 減弱によって病原性の低 い細菌が常在部位から侵入して感染したものと思われ た、いずれにしろ典型的な急性型の症状を呈する場合は ともかく, 慢性型, 特に良性の経過をとるものでは臨床 症状に乏しく，原因不明の不定の訴之のみをみることが 多く，讋断が困難となるが，原因不明の小感染を反復す る場合には血液検查をすることが望ましいと思われ $3^{15)}$ 次に治療についてであるが，その第 1 は本症をひ き扣こした薬剤あるいは物質をただちに中止することで あり，次いで感染症に対する治療である ${ }^{16)}$. この際, 炎 症部位よりの細菌培養を行って菌に対する感受性を調べ てから投与すべき抗生物質を決定するのが理想的である が，通常はその余裕がないので，抗菌スペクトルが広 く，骨䯣障害の少ない薬剂，たとえば合成ペニシリンや 
セファロスポリン系の薬剤を投与するのが適当と思われ る。その他，副腎皮質ステロイド剤や $\mathrm{ACTH}$ の投与， さらに最近ではケーグロブリン製剂を用いることもあり， 重症感染症に対してしばしば劇的な効果をもたらしてい る.

本症例ではこれらの抗生物質を感染早期に，抜歯など の処置を行ら際には術前に，通常の1.5〜2倍量を目安之 した十分な量を投与し, 合作症や重症感染症への移行の 防止に努めた。 また，抗生物質の他に抜歯後疼痛に対し て Solantal, Mebronなども投与されたが，これらが本 症例の顆粒球減少をさらに促進, 悪化せしめるといら事 実は観察されなかった。これらの療法とともに口腔内を 清潔に保つことも大切で, 常に感染の予防とその対策を 構じることが重要である.

本症の予後を左右する因子としては症候の軽重, 合併 症（特に敗血症など重症感染）, 他の血球系の障害の有 無などがあげられており，一般には薬阂性のものの方が 原因不明のものより予後は良いといわれている ${ }^{17)}$.

本症例は初めに顆粒球減少症と診断されてからすでに 約 7 年を経過しており, 症状は比較的軽度で, 慢性に経 過して感染を反復する慢性顆粒球減少症であり, 骨髄所 見とも合わせて子後は比較的良好と思われるが，本症を 経て白血病を発現した症例も報告されており ${ }^{18,19)}$ ，今後 とも経過観察, 随歭の血液検查等が必要であると考えて いる.

\section{ま と め}

3 歳時に発症した原因不明の慢性顆料球減少症で, こ れまで皮麿，粘膜の感染症を反復した症例を報告した。 血液検查に拈いて好中球の消失, 出現がしばしば周期的

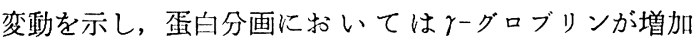
し, 免疫グロブリン分画における IgG はじめ IgA, IgM の著しい増加を認めた。

口腔病変は常に慢性㴹肉炎の状態を呈し, これに加え 顎骨の吸収, 発育不全もみられ，ときに潰瘍を形成した り，急性顎炎を併発した。感染症は口腔常在菌による二 次感染と思われるが, 病状は長期化し, 治癒は遅い傾向 がみられた。そこで抜齿等の外科的侵襲を加える際には 術前に臨木検査を行い, さらに抗生物質の術前投与をし て合併症の防止に努めることが必要と思われた。
本論文中の要旨は昭和53年 4 月 5 日, 第33回日本口腔 科学会総会 (於東京) に拉いて発表した。

\section{引用 文 献}

1）荒川雅男，他編：現代小児科学大系，第14巻, 血液疾患。第 1 版, 中山書店, 東京, 1969, 185頁.

2）長谷川弥人，他編：臨床血液学。第 2 版，医学 書院, 東京, 1974, 434頁.

3）宮地敬子, 他：先天性無顆粒球症の 2 症例。臨 床血液 30：443 1977.

4) Stuart, C. Finch.: Hematology. 中尾喜久, 他 訳。第 1 版，広川書店，東京，1977，740頁。

5) 馬場一雄, 他編：小児の正常値. 第 1 版, 医学 書院, 東京, 1977, 100頁.

6) 大久保滉：顆粒球減少症。新内科学大系，血 液・造血器疾患 II a 、第 1 版, 中山書店, 東京, 1978，315頁.

7) Rohr, K.: Das menschliche Knochenmark, 3 te Auf, Georg-Thieme, Stuttgart, 1960.

8) Wintrobe, M.M.: Clinical Hematology. ed 6, Lea \& Febiger, Philadelphia, 1967.

9) 大久保滉：薬物アレルギーによる骨䯣障害. 臨床科学 7:685 1971 .

10）松本 昇, 他：抗甲状腺凨に上る顆粒球減少症. 臨床血液 17：82 1976.

11)大久保滉：日本における薬物の血液障害。臨 床血液 15: 2301974.

12) Bauer, W.H: The supporting tissues of the tooth in acute secondary agranulocytosis. J Dent Res 25: 5011946.

13）宮崳澄婎：小児に打忊る続発性（二次性）免疫 不全症候群。小児内科 10：1185 1978.

14) 藤田尚男, 藤田恒夫 : 標淮組織学総論. 第 1 版, 医学書院, 東京, 92, 1975.

15）斉藤害治, 他 : Chronic idiopathic neutropenia の 1 例。臨床血液 19: 311978.

16) 内野治人, 他編: 病態血液学. 第 1 版, 南江堂, 東京, 1977，239頁.

17) 織田敏次, 他編 : 内科七ミナ一, 白血病。第 1 版, 永井書店, 大阪, 1978，351頁。

18）林英夫，他：無顆粒球症を経て急性骨䰹性白 血病を発症した 1 例. 臨床血液 19: 13791978.

19）四宮笵明，他 · 8 ケ月間好中球減少症が認めら れた後, 急性リンバ性白血病を発症した幼㫛 例。臨林血液 19：1569 1978. 